\title{
AN INVESTIGATION INTO STUDENTS' EVALUATION OF AND ATTITUDES TOWARDS SYNCHRONOUS COMPUTER-MEDIATED COMMUNICATION ON LANGUAGE SKILLS DEVELOPMENT IN VIETNAMESE INSTITUTIONAL CONTEXT
}

\author{
Pham Dang Tram Anh* \\ Danang University of Medical Technology and Pharmacy \\ 99 Hung Vuong, Hai Chau, Danang, Vietnam \\ Received 28 August 2018 \\ Revised 7 March 2019; Accepted 27 May 2019
}

\begin{abstract}
The study explored students' evaluation of and attitudes towards synchronous computermediated communication (SCMC) on language skills development after a fifteen-week semester of instruction, using quantitative and qualitative approach. One class of English level 3 of CEFR - Vietnamese standard (B1) participated in oral role plays and one class engaged in synchronous online discussions. The research participants filled out the pre- and post- questionnaires and the participants from the SCMC group were called for semi-structured interviews to obtain their evaluation and attitudes towards synchronous computer-mediated communication on language development. Analysis of the questionnaires and semistructured interviews exposed that the fifteen-week semester English intensive course contributed to students' language skills development. They had positive attitudes towards SCMC and were contented with the activities in the computer lab. Remarkably, the SCMC group felt more confident in chatting in computer lab than the role play group. It showed that doing written online discussions would intrigue learners in their learning English. SCMC is thus shown to be a valuable addition to the foreign language classroom.
\end{abstract}

Keywords: synchronous computer-mediated communication, oral role plays, students' evaluation, attitudes, language skills development, foreign language classroom

\section{Introduction}

During the last decades, research on computer mediated communication (CMC) has shown an outstanding development on foreign language teaching and learning methodology using technology of which countless benefits have been proved through numerous world-wide research studies.

CMC has two modes: asynchronous computer-mediated communication

\footnotetext{
Tel.: 84-905111697
}

Email: anhpham.dumtp@gmail.com
(ASCMC) and synchronous computermediated communication (SCMC). Generally, asynchronous computer-mediated communication (ASCMC) takes place in time and place independence. Typically, the instructor and students discuss, give and get information or deliver materials through course web pages, posting of forum messages, or email messages. In contrast, synchronous computer-mediated communication (SCMC) represents real-time interactions. Usually, this means that the instructor and students meet in a text chat room, simultaneously, at a particular 
location in cyberspace or from any location that has Internet access and interact through typed statements or questions (Lavooy \& Newlin, 2003). In this study, SCMC is used as synchronous online discussion or text chat or written chat interchangeably.

Previous research studies showed that there is a link between oral communication and online synchronous discussions. Online synchronous discussions not only improve written proficiency but also indirectly improve oral proficiency since writing in a computermediated environment resembles spoken language in terms of its interactional features (Beauvois, 1997b; Chun, 1994).

Considering the increasing use of technology in today's language classrooms in Vietnam, the current research is needed to examine students' evaluation of and attitudes towards SCMC on language skills development.

\section{Literature review}

\subsection{CMC and language skills development}

CMC's contribution to language skills development has constantly been proved since the early period in CMC's history. Various metalinguistic aspects of language development have been explored, including negotiation of meaning, sociolinguistic environment, and intercultural competence. Furthermore, numerous studies on interactionist approach as well as a sociocultural viewpoint to second language acquisition (SLA) have been conducted on negotiation of meaning and CMC (Chun, 2008). In addition, Kitade (2000)'s findings showed that CMC is a profitable environment for sociolinguistic development. This study concluded that interactional features of CMC facilitated encouraging conditions for developing positive attitudes towards language learning: no turn-taking competition, text-based interaction, and a lack of nonverbal cues.

Additionally, increasing in linguistic competence, both quality and quantity, among learners has also been stated in the study by Kern (1995). He revealed that CMC-supported learners created more language production than their friends in the face-to-face (FTF) group. Kern found that SCMC discussions produced between two and four times more turns, more sentences, and more words than the oral discussions. The research also showed that learners' language production was at a greater level of sophistication regarding grammatical accuracy and complexity.

Finally, in terms of language skills, both written and spoken skills are enhanced through various modes of CMC in language learning projects. In fact, there is a common tendency to associate $\mathrm{CMC}$ with the development of specific language skills (Levy \& Stockwell, 2006). The hypothesis that SCMC may improve speaking proficiency has been tested by Payne and Whitney (2002), who found that participants in a text chat room have a significantly higher oral proficiency than those just spending time in traditional oral classes.

In short, it can therefore be seen that SCMC has been used widely in developing most language areas and skills, except for listening skills which are normally supported and developed through other forms of visual and audio technology. The text-based nature of SCMC brings about many meaningful applications in language education. This medium not only amplifies students' attention to linguistic forms (Wang, 2004), but also stimulates increased written production of the target language as well as creating a less stressful and more equitable environment for discussion (Nguyen, 2010). 


\subsection{Synchronous computer-mediated communication}

A wide range of potential strengths of SCMC mode have been found in previous studies. SCMC enhances learning opportunities for students according to Berge (1995). SCMC not only provides more in-depth interactions on topics; it is also convenient and useful for students living long distances from the university, travelling frequently, having family obligations (childcare responsibility) or disabilities that affect mobility as in the study by Lavooy and Newlin (2003). Candace (2004) claimed that SCMC creates more spontaneous communication going back and forth, enhances learning intertests and interpersonal relationship. She adds that students are more engaging and have more equal distribution in asking and answering questions during communication processes. Candace also proved that there is a higher percentage of socio-emotional interactions; learners asked more personal questions and revealed more about their frustration or need for help with less hesitation. The students have stronger sense of immediacy to respond to peers' questions and spend less time to send messages (Candace, 2004). In addition, Khamis (2010) stated that text scripts can be always retrieved for later reference via SCMC which is a backbone of distance learning programs. His research proved that SCMC facilitates instructor-student and studentstudent interactions as well as provides natural byproducts of authentic communicative activities. In Watt's study, SCMC's benefit is that it is easier to provide immediate feedback to information seekers (Watts, 2016).

Likewise, the most common benefits that were found in research studies investigating the perceptions of SCMC are: reduced anxiety, increased and equalized participation among language students, and increased language output. Often, research studies report that these factors have an impact on one another, i.e., the reduced anxiety level that is prevalent in an SCMC environment leads to increased and equalized participation among students, which in turn leads to more language production. The question that arises is why learners experience a discussion in a computer lab so differently from an oral discussion in the classroom.

In order to capitalize these SCMC's advantages and explore its possible influences on classroom language learning, the present study investigates students' evaluation and attitudes towards SCMC on language skills development in Vietnamese institutional context.

\section{Methodology}

\subsection{Research Design}

In order to achieve the aim of this study, a mixed approach was chosen. The researcher collected numeric details from quantitative data and specific information from qualitative data. Both quantitative and qualitative data were analyzed to explore students' evaluation and attitudes towards synchronous computer mediated communication between two groups of EFL learners: the face-to-face role play group (oral role play) and the SCMC group using synchronous online discussion (written chat).

\subsection{Research question}

This study is guided by the following research question: What are the students' evaluation of and attitudes towards SCMC on language skills development in Vietnamese institutional context?

\subsection{Participants}

The following table shows the students' self-rating English language ability reflected relatively traditional teaching and learning 
methodology. The students expressed more confidence in reading comprehension and grammar with the mean score of 3.87 than in listening and speaking with the mean score of 2.23 , and 2.33 respectively in the 5-point scale with 5 indicating the strongest. Most participants self-rated their English language proficiency at moderate level or lower in all language skills and areas: listening: 96.7\%, speaking: 100\%, reading: $96.7 \%$, writing: 96.7\%, grammar: $86.7 \%$, vocabulary: $96.7 \%$ and pronunciation: $93.3 \%$.

Table 1. Self-rated English language proficiency between the two groups

\begin{tabular}{|c|c|c|c|c|c|c|}
\hline Skills & Group & $\mathrm{n}$ & Mean & SD. & $\mathrm{t}$ & $\mathrm{p}$ \\
\hline \multirow[t]{2}{*}{ Listening } & Role play & 15 & 2.07 & .961 & \multirow[t]{2}{*}{-1.066} & \multirow[t]{2}{*}{.296} \\
\hline & SCMC & 15 & 2.40 & .737 & & \\
\hline \multirow[t]{2}{*}{ Speaking } & Role play & 15 & 2.47 & .640 & \multirow[t]{2}{*}{1.214} & \multirow[t]{2}{*}{.235} \\
\hline & SCMC & 15 & 2.20 & .561 & & \\
\hline \multirow[t]{2}{*}{ Reading } & Role play & 15 & 3.87 & .516 & \multirow[t]{2}{*}{.00} & \multirow[t]{2}{*}{1.000} \\
\hline & SCMC & 15 & 3.87 & .352 & & \\
\hline \multirow[t]{2}{*}{ Writing } & Role play & 15 & 2.53 & .743 & \multirow[t]{2}{*}{-.887} & \multirow[t]{2}{*}{.382} \\
\hline & SCMC & 15 & 2.73 & .758 & & \\
\hline \multirow[t]{2}{*}{ Grammar } & Role play & 15 & 3.93 & .594 & \multirow[t]{2}{*}{.574} & \multirow[t]{2}{*}{.571} \\
\hline & SCMC & 15 & 3.80 & .676 & & \\
\hline \multirow[t]{2}{*}{ Vocabulary } & Role play & 15 & 2.67 & .617 & \multirow[t]{2}{*}{.581} & \multirow[t]{2}{*}{.566} \\
\hline & SCMC & 15 & 2.53 & .640 & & \\
\hline \multirow[t]{2}{*}{ Pronunciation } & Role play & 15 & 2.53 & .834 & \multirow[t]{2}{*}{.00} & \multirow[t]{2}{*}{1.000} \\
\hline & SCMC & 15 & 2.53 & .743 & & \\
\hline
\end{tabular}

Furthermore, as shown in Table 1, there was no significant difference between the two treatment groups regarding the language skills and areas mentioned ( $p>.05)$. The least similarity of the perceived language proficiency between the two groups was the speaking skill with the $\mathrm{p}$ value at .235 , still far away from the significant level of .05. In general, both groups shared a similar level of perceived language competence, which made the selection of either group to be an SCMC class and the other, a control class less challenging and later comparisons between the two groups more confident. This would ensure the reliability of the research and help the researcher control confounding factors during treatment.

\subsection{Instruments}

In order to explore students' evaluation and attitudes towards SCMC on language development, the researcher used the following research instruments. First, the pretreatment questionnaire was distributed to the two selected classes after the participants had been briefed on the purpose of the study, and had an opportunity to ask questions about what would be involved. The questionnaire included questions about students' demographic information and attitudes towards computer use for English learning, which helped to attain a better understanding of the students' individual, socio-cultural, and academic backgrounds prior to the treatment activities. Second, the post-treatment questionnaire was applied to explore students' attitudes towards the use of synchronous online discussions on the language development. The items on the questionnaires were adapted from surveys used in similar research studies (Kost, 2004; Nguyen, 2011) and chosen based on 
the current study's purposes. Both pre- and post-treatment questionnaires were piloted on ten students for revising any ambiguous questions.

In addition, an interview for SCMC group was developed to help the researcher collect more detailed, qualitative information by, for example, giving the reasons why participants have such evaluations and attitudes. The interview design of the current study was semi-structured to invite more profound thoughts about SCMC language skills classes. The students' English proficiency was rated insufficient to understand and answer all interview questions in English. Therefore, all the interviews were conducted in Vietnamese for analysis. All interviews were audio recorded and transcribed for evaluating students' reflections on and attitudes towards SCMC application in language classes.
Notably, transcripts of the interviews were put into word documents and emailed to individual students to request any modifications.

\subsection{Tasks in the lab}

The students went to the computer lab for 4 contact hours per week to carry out the designed tasks. The researcher developed all the communicative web-based activities that the students completed in the computer lab, and sent them to the students via email. The activities usually consisted of a guided Internet-based information search, followed by an oral role play or chat depending on treatment group. The activity was preceded by an online vocabulary-reviewing exercise from the previous session to help the student revise and expand their vocabulary.

An example of a web activity is presented below:

City Break!

A brother and sister are going to spend a weekend visiting a big city with their parents. Discuss the different things they could do there and say which would be most enjoyable.

Make a list:

1. What kinds of activities do you want to do?

Look for these activities on the provided links and write down:

1. When and how do you want to do those activities?

2. Choose the most enjoyable thing you want to do and develop strong arguments to support your choice.

The most popular activities to do in a big city are: Go on a free walking tour, Explore the markets, Visit free museums and galleries, Hang out with the locals, Stroll around the park, Check out libraries, churches and cathedrals, Do window shopping, Go on a hop on hop off bus tour.

Now do oral role play/chat and discuss with your partner which activities you can do together in the city. What is the most enjoyable for you? You should both be happy with the decision!

The web activities were structured according to the same principles: two or three students worked together as a group whereby each had access to their own computer. The instructor assigned group members at their discretion; sometimes she paired students up according to their language levels, sometimes students asked the instructor to do so for them. Students read the assignment, which gave them step-by-step instructions of how to proceed and which topics to cover in their Internet search, and then clicked on one of the 
provided links. Approximately 50 minutes before the end of the lesson, the instructor asked students to engage in the assigned role plays based on the information they had found through their web search. While the SCMC group used the hangout program of Gmail to do their role plays in the time given, the oral role play group engaged in oral pair or group work and finally, they performed 2-3 role plays in front of the class at the very end of the lesson. As for the SCMC group, the instructor created a Hangout group of the entire class and pasted students' mistakes during chatting one by one. Responding to the mistake pasted by the instructor, students sent their correct sentence to the group window. The instructor moved to another mistake only when the posted mistake had been corrected.

\subsection{Research procedures}

The researcher carried out the following research procedures to reach the aim of the study.

Table 2. Overview of the research procedures

\section{Pre-treatment measurement instruments}

1. Pre-treatment questionnaire

While-treatment

Role play group in the computer lab

Conducted by researcher

- Provide topics and links via email

- Assign topic, instruct, explain and answer questions relating to the topic

- Provide assistance by speaking to students

- Feedback on mistakes while circling around

Performed by students

- Do web-based activities

- Click on the provided links for topic-related information

- Do oral role play

- Correct mistakes

- Present 2-3 role plays in whole group

\section{Post-treatment measurement instruments}

2. Post-treatment questionnaire

3. Semi-structured interview

\subsection{Data analysis}

All the items of the pre- and post-treatment questionnaires were calculated and compared with the standard of Cronbach's Alpha using SPSS system. The post-treatment sets of questionnaire were rated on a five-point Likert scale. Mean scores of students' attitudes towards oral role plays and written chats were computed by treatment group, assigning the score of 5 to the highest rating ("strongly
Chat group in the lab

Conducted by researcher

- Provide topics and links via email

- Assign topic, instruct, explain and answer questions relating to the topic

- Provide assistance by sending messages

- Feedback on mistakes while joining Hangout group

Performed by students

- Do web-based activities

- Click on the provided links for topic-related information

- Write chat messages

- Read suggestions/feedback from instructor

- Send correct sentences responding to posted mistakes 


\section{Findings and discussion}

The post-treatment questionnaire was rated on a five-point Likert scale. Generally, most mean scores were slightly above or slightly below the "neutral" point (worth 3 points) which resulted in a very balanced picture. Interview audio-recordings were transcribed and sent back to participants for clarification before analysis in details and in depth of their attitudes towards and evaluation of SCMC on language skills development.
4.1. Students'evaluation of oral role play and SCMC on four language skills

The first several questions of the questionnaire asked students' evaluation of the treatment on their language skills. It was assumed that responses would point to positive effects of the oral role plays on speaking and listening skills, and to positive effects of the online discussions on reading and writing skills. The following table confirms these assumptions.

Table 3. Students' evaluation of oral role play and SCMC on four language skills

\begin{tabular}{|c|c|c|c|c|c|}
\hline Treatment & Item & Mean & $\mathrm{SD}$ & $\mathrm{t}$ & $\mathrm{p}^{*}$ \\
\hline Role play & $\begin{array}{l}\text { Doing role plays improved my ability to write in } \\
\text { English. }\end{array}$ & 3.73 & .961 & \multirow[t]{2}{*}{.000} & \multirow[t]{2}{*}{1.000} \\
\hline SCMC & $\begin{array}{l}\text { Using written chat improved my ability to write in } \\
\text { English. }\end{array}$ & 3.73 & .884 & & \\
\hline Role play & $\begin{array}{l}\text { Doing role plays improved my ability to read in } \\
\text { English. }\end{array}$ & 3.87 & .640 & \multirow[t]{2}{*}{-.543} & \multirow[t]{2}{*}{.592} \\
\hline SCMC & $\begin{array}{l}\text { Using written chat improved my ability to read in } \\
\text { English. }\end{array}$ & 3.73 & .704 & & \\
\hline Role play & $\begin{array}{l}\text { Doing role plays improved my ability to speak in } \\
\text { English. }\end{array}$ & 4.07 & .799 & \multirow[t]{2}{*}{2.729} & \multirow[t]{2}{*}{.012} \\
\hline SCMC & $\begin{array}{l}\text { Using written chat improved my ability to speak in } \\
\text { English. }\end{array}$ & 3.40 & .507 & & \\
\hline Role play & $\begin{array}{l}\text { Doing role plays improved my ability to listen in } \\
\text { English. }\end{array}$ & 3.80 & .775 & \multirow[t]{2}{*}{3.523} & \multirow[t]{2}{*}{.002} \\
\hline SCMC & $\begin{array}{l}\text { Using written chat improved my ability to listen in } \\
\text { English. }\end{array}$ & 2.67 & .976 & & \\
\hline
\end{tabular}

*Significant at $\mathrm{p}<.05$

Many participants of SCMC group stated that online discussions provided them with opportunities to improve writing and reading skills in English (3.73). What is far more interesting, however, is that more than three fifths of the SCMC group also agreed that the online discussions improved their ability to speak (3.40). It seems to show that the hybrid nature of synchronous online communication, which combines the speed and informality of oral speech with written output, addresses language skills on either side of the spectrum. This finding corroborates with Chun's (1994) and Payne and Whitney (2002)'s studies. They both claim that language skills practiced in electronic discussions can be transferred to oral skills and that synchronous chat develops the same cognitive mechanisms 
as oral speech. The finding also shows that participants perceived they improved their listening skills over the course. It is obvious to learn that many participants of the role play group revealed that their listening skills were improved (3.80) because their speaking and listening skills were required during oral role plays, the CMC group also endorsed that they improved their listening skills. Participant 3127 in the post-interview uttered: "The most interesting thing during the course is listening to the instructor. I like listening to her a lot. Listening to her I can improve my listening skill". There were statistically significant differences between the two treatments regarding speaking and listening skills with $\mathrm{p}=.012$ and $.002(\mathrm{p}<.05)$.

\subsection{Students' attitudes towards oral role play and SCMC}

\subsubsection{Attitudes}

As the following table shows, both treatment groups seem to have positive attitudes using either oral role plays or synchronous online discussions in their English intensive class.

Table 4. Students' attitudes towards oral role play and SCMC in language skills classes

\begin{tabular}{|c|c|c|c|c|c|}
\hline Treatment & Item & Mean & SD & $\mathrm{t}$ & $\mathrm{p}^{*}$ \\
\hline Role play & $\begin{array}{l}\text { Doing role plays in the computer lab was a positive } \\
\text { addition to English intensive class. }\end{array}$ & 3.37 & .516 & \multirow[t]{2}{*}{1.043} & \multirow[t]{2}{*}{.310} \\
\hline SCMC & $\begin{array}{l}\text { Using chat in the computer lab was a positive } \\
\text { addition to English intensive class. }\end{array}$ & 3.83 & 1.125 & & \\
\hline Role play & The role plays were too short. & 3.07 & .704 & \multirow[t]{2}{*}{1.437} & \multirow[t]{2}{*}{.162} \\
\hline SCMC & The chat sessions were too short. & 3.67 & .816 & & \\
\hline Role play & $\begin{array}{l}\text { I felt more confident participating in the role plays } \\
\text { than in the regular class. }\end{array}$ & 3.13 & .915 & \multirow[t]{2}{*}{1.538} & \multirow[t]{2}{*}{.136} \\
\hline SCMC & $\begin{array}{l}\text { I felt more confident participating in the chat than } \\
\text { in the regular class. }\end{array}$ & 3.60 & .737 & & \\
\hline Role play & $\begin{array}{l}\text { I would have preferred to do an online chat instead } \\
\text { of an oral role play. }\end{array}$ & 3.13 & 1.125 & \multirow[t]{2}{*}{1.381} & \multirow[t]{2}{*}{.178} \\
\hline SCMC & $\begin{array}{l}\text { I would have preferred to do an oral role play } \\
\text { instead of the chat. }\end{array}$ & 2.60 & .986 & & \\
\hline Role play & $\begin{array}{l}\text { The time we spent on the role plays could have } \\
\text { been used more productively as regular class time. }\end{array}$ & 3.33 & .900 & \multirow[t]{2}{*}{.435} & \multirow[t]{2}{*}{.667} \\
\hline SCMC & $\begin{array}{l}\text { The time we spent on the chat could have been used } \\
\text { more productively as regular class time. }\end{array}$ & 3.20 & .775 & & \\
\hline Role play & $\begin{array}{l}\text { I would have liked to do more role plays in small } \\
\text { groups (instead of just with my partner). }\end{array}$ & 3.20 & .775 & \multirow[t]{2}{*}{.215} & \multirow[t]{2}{*}{.831} \\
\hline SCMC & $\begin{array}{l}\text { I would have liked to chat more often in small } \\
\text { groups (instead of just with my partner). }\end{array}$ & 3.13 & .915 & & \\
\hline Role play & $\begin{array}{l}\text { I enjoy written assignments more than role plays } \\
\text { because they allow me to monitor my use of } \\
\text { grammar and vocabulary, and to be creative and } \\
\text { play around with the language. }\end{array}$ & 3.53 & .915 & \multirow[t]{2}{*}{1.342} & \multirow[t]{2}{*}{.190} \\
\hline SCMC & $\begin{array}{l}\text { I enjoy oral role plays more than written } \\
\text { assignments (e.g., essays), because they allow me } \\
\text { to be creative and play around with the language. }\end{array}$ & 2.93 & .704 & & \\
\hline Role play & \multirow{2}{*}{$\begin{array}{l}\text { Networked computers have positive contribution to } \\
\text { language learning. }\end{array}$} & 4.20 & .676 & \multirow[t]{2}{*}{.983} & \multirow[t]{2}{*}{.334} \\
\hline SCMC & & 4.87 & 1.125 & & \\
\hline
\end{tabular}


The SCMC and role play groups evaluated the addition of chat and role play in computer lab as beneficial (3.83 vs. 3.37). Either group was quite content with the activities they did in the computer lab when asked about the time for doing role plays or chats as their mean scores were just a bit higher than neutral point. The SCMC group seemed to enjoy their chat sessions as they wished they could have more time to chat (3.67) compared to oral role play group (3.07). A comparison to the pre-treatment questionnaire furthermore supported these findings: The SCMC group felt more confident in chatting in computer lab than the role play group (3.60 vs. 3.13). Far more interesting when asked whether they would have preferred the other treatment, only 2.60 SCMC group preferred to do an oral role play instead of the chat, while 3.13 oral role play group preferred to chat instead of role play. It showed doing written online discussions would intrigue learners in their learning English. The majority of SCMC group emphasized the great contribution of networked computers to language learning (4.87). As observed in Table 4, the other items displayed a balanced picture between the two groups.

\subsubsection{Anxiety}

All participants experienced a high level of comfort in their classes. They did not feel very stressed when they had to perform oral role plays in the regular class or answer the questions, and they did not let pronunciation hinder their expressing themselves. At the same time, however, the students wished they had more time to "compose good English".

Table 5. Students' anxiety during oral role play and written chat

\begin{tabular}{|c|c|c|c|c|c|}
\hline Treatment & Item & Mean & SD & $\mathrm{t}$ & $\mathrm{p}^{*}$ \\
\hline Role play & \multirow{2}{*}{$\begin{array}{l}\text { I often feel "put on the spot" when doing role plays } \\
\text { in English and wish I had more time to compose } \\
\text { "good English" when asked to do a role play. }\end{array}$} & 3.07 & 1.033 & \multirow[t]{2}{*}{-.650} & \multirow[t]{2}{*}{.521} \\
\hline SCMC & & 3.40 & 1.242 & & \\
\hline Role play & \multirow{2}{*}{$\begin{array}{l}\text { I usually do not feel stressed when answering a } \\
\text { question or doing role plays in the regular class. }\end{array}$} & 3.33 & .976 & \multirow[t]{2}{*}{.784} & \multirow[t]{2}{*}{.439} \\
\hline SCMC & & 3.07 & .884 & & \\
\hline Role play & $\begin{array}{l}\text { Having to worry about pronunciation made me feel } \\
\text { a lot less comfortable in the role plays. }\end{array}$ & 3.53 & 1.060 & \multirow[t]{2}{*}{.000} & \multirow[t]{2}{*}{1.000} \\
\hline SCMC & $\begin{array}{l}\text { Not having to worry about pronunciation made } \\
\text { me feel a lot more comfortable in the online } \\
\text { discussions. }\end{array}$ & 3.63 & .990 & & \\
\hline
\end{tabular}

While the mean scores showed a good comfort level and little anxiety for both groups, it was interesting to note that the CMC group considered it slightly more helpful (3.63) not to have to pay attention to pronunciation when engaging in their online discussions. This response corroborated findings from other research studies (Abrams, 2003; Kost, 2004) where participants commented on the benefits of online discussions in which pronunciation was not an issue, thus freeing up cognitive energy for other aspects of the conversation. The role play group felt equally comfortable and not worried about pronunciation, which might be due to a low level of anxiety in the classes. Participant 3129 uttered in the interview: "I don't worry at all. When I see my friends' text on the screen, I reply. If I don't understand it, I ask again. It is just a practice hour, so I feel free to write what I want or wait for my friends to give their ideas". 


\subsubsection{Monitoring mistakes}

A very interesting aspect of language practice was monitoring and noticing of mistakes. According to the participants' selfreported answers, students in the SCMC group reported their own monitoring the use of grammar and vocabulary (3.33) and noticing of other students' mistakes (3.53) when they conversed in the synchronous online discussions.

Table 6 . Students' monitoring mistakes via oral role play and written chat

\begin{tabular}{|c|c|c|c|c|c|}
\hline Treatment & Item & Mean & SD & $\mathrm{t}$ & $\mathrm{p}^{*}$ \\
\hline Role play & $\begin{array}{l}\text { I monitored my use of grammar and vocabulary in } \\
\text { the oral role plays in the lab more than I usually do } \\
\text { in the classroom. }\end{array}$ & 3.27 & .704 & \multirow[t]{2}{*}{-.196} & \multirow[t]{2}{*}{.846} \\
\hline SCMC & $\begin{array}{l}\text { I monitored my use of grammar and vocabulary in } \\
\text { the chat messages more than I usually do in oral } \\
\text { communication. }\end{array}$ & 3.33 & 1.113 & & \\
\hline Role play & $\begin{array}{l}\text { I noticed other students' mistakes more when they } \\
\text { presented their oral role plays in the lab than in oral } \\
\text { communication in the regular class. }\end{array}$ & 3.27 & .884 & \multirow[t]{2}{*}{-.772} & \multirow[t]{2}{*}{.476} \\
\hline SCMC & $\begin{array}{l}\text { I noticed other students' mistakes more when } \\
\text { conversing in the chat than in oral communication } \\
\text { in the regular class. }\end{array}$ & 3.53 & 1.125 & & \\
\hline
\end{tabular}

As can be observed in Table 6, the oral role plays challenged students to monitor their own use of grammar or vocabulary and to notice other students' mistakes when they presented their role plays but with lower tendency (3.27). Participant 3121 said, "It is much easier for me to correct my friends' and my mistakes when looking at the text on the screen than speaking to friends. I also noticed my friends' wrong spellings. I like the correct part at the end of the session". Considering the fact that the online discussions lasted for only about 50 minutes per week, the positive reaction of the students seemed to point to a great but hardly exploited potential of SCMC discussions.

In general, both treatment groups had positive attitudes towards the use of synchronous computer-mediated communication on language skills development. The SCMC and role play groups evaluated the addition of written chat and oral role play in computer lab as beneficial. They were quite contented with the activities they did in the computer lab. Remarkably, the SCMC group felt more confident in chatting in computer lab than the role play group. It showed doing written online discussions would intrigue learners in their learning English. In addition, all participants experienced a high level of comfort in their classes. Finally, according to the participants' self-reported answers, students in the SCMC group reported their own monitoring the use of grammar and vocabulary and noticing of other students' mistakes when they conversed in the synchronous online discussions.

\section{Limitations of the study and future research}

This study investigated the students' evaluation and attitudes towards the use of synchronous computer-mediated communication on language development. The actual treatment including 4 contact hours in the computer-assisted classroom per 
week was too short to gain more conclusive results. Due to institutional constraints, a longer treatment phase was not possible for this study. However, in order to find more support for the indicated tendency, it would be necessary to replicate this study with a treatment which distinguishes the two groups more clearly, i.e., expanding the chat sessions to two or more lessons per week. A more longitudinal study, over two or more semesters, would also lend support to a clearer understanding of the phenomena under investigation.

Obviously, it is also difficult to draw conclusions about students' attitudes towards the use of SCMC in language classes based on only 30 participants whose language data were examined in this study. In order to obtain a more thorough representation, it is necessary to investigate the language data from a larger sample of learners, and not just 30 participants.

Based on the data collected from the questionnaire, it seems obvious that students enjoyed the chat sessions. For future research purposes, it would be important to follow up on these issues, for example by investigating the effect of synchronous online discussion on students' language skills development, or designing a more qualitatively oriented survey to investigate students' motivation and their attitudes towards the use of technology in a language class. Furthermore, it would also be interesting to explore these aspects in a larger context and to see how their attitudes and motivation levels would influence their learning of the foreign language. Additionally, the population of 30 participants is too limited to validate the quantitative data and to make the sample representative for the entire population. Future research is advised to collect data from a larger sample.

\section{Conclusion}

The goal of this study was to provide more insight into SCMC application in language skills classes. The result proved SCMC had great contribution to language development. The students had positive attitudes towards the use of technology in their language classes.

However, in order to shed further light on this issue, more studies investigating learners' language skills development with the use of SCMC are needed.

\section{References}

Beauvois, M. H. (1997b). Computer-mediated communication (CMC): Technology for improving speaking and writing. In Technology-Enhanced Language Learning (165-183). Lincolnwood: National Textbook Company.

Berge, L. Z. (1995). Facilitating computer conferencing: Recommendations from the field. Educational Technology, 35, 22-30.

Candace, C. C. (2004). A Model of Learner-Centered Computer-Mediated Interation For Collaborative Distance Learning. International Journal on $E$ Learning, 3(1), 11-18.

Chun, D. (1994). Using computer networking to facilitate the acquisition of interactive competence. System, 22, 17-31.

Chun, D. (2008). Computer-mediated discourse in instructed environments. In S. Magnan, Mediating discourse online (15-46). Amsterdam: John Benjamins.

Kern, R. (1995). Restructuring classroom interaction with networked computers: Effects on quantity and characteristics of language production. The Modern Language Journal, 79(4), 457-476.

Khamis, H. (2010). Communication Strategies in Computer-Mediated Communication: An Egyptian EFL Context. CALICO Journal, 28(1), 35-48.

Kitade, K. (2000). L2 learners discourse and SLA theories in CMC: Collaborative interaction in Internet chat. Computer Assisted Language Learning, 13(2), 143-166.

Kost, C. (2004). An investigation of the effects of synchronous computer-mediated communication (CMC) on interlanguage development in beginning learners of German: Accuracy, proficiency, and communication strategies. Doctoral Dissertation, The University of Arizona.

Lavooy, M. J., \& Newlin, M. H. (2003). Computer Mediated Communication: Online Instruction and Interactivity. JI. of Interactive Learning Research, 14(2), 157-165. 
Levy, M., \& Stockwell, G. (2006). CALL dimensions: Options and issues in computer-assisted language learning. Mahwah: NJ: Lawrence Erlbaum Associates.

Nguyen, Long Van (2010), Computer mediated collaborative learning within a communicative language teaching approach: A sociocultural perspective. Asian EFL Journal, 12(1), 201-233.

Nguyen, Long Van (2011). Computer-mediated collaborative learning in a Vietnamese tertiary EFL context: Process, Product, and Learners' Perceptions. Palmerston North, New Zealand: Unpublished Doctoral Dissertation, Massey University.
Payne, J., \& Whitney, P. (2002). Developing L2 oral proficiency through synchronous CMC: Output, working memory, and interlanguage development. CALICO, 20(1), 7-32.

Wang, Y. (2004). Supporting synchronous distance language learning with desktop videoconferencing. Language Learning \& Technology, 8(3), 90-122.

Watts, L. (2016). Synchronous and asynchronous communication in distance learning. The Quarlerly Review of Distance Education, 17(1), 23-32.

\title{
NGHIÊN CỮU SỰ ĐÁNH GIÁ VÀ THÂI ĐỘ CỦA SINH VIÊN VỀ GIAO TIẾP ĐỒNG THƠ'I QUA TRUNG GIAN MÁY TÍNH ĐỐI VỚI VIỆC PHÁT TRIỂN KỸ NĂNG NGÔN NGỮ TRONG BỐI CẢNH GIÁO DỤC VIỆT NAM
}

\author{
Phạm Đặng Trâm Anh \\ Trương Đại học Kỹ thuật $Y$-Dược Đà Nẵng \\ 99 Hùng Vurong, Hải Châu, Đà Nã̃ng, Việt Nam
}

Tóm tắt: Nghiên cứu này điều tra thái độ và đánh giá của sinh viên về giao tiếp đồng thời qua trung gian máy tính đối với việc phát triển kỹ năng ngôn ngữ sau một học kỳ gồm 15 tuần, sử dụng phương pháp định lượng và định tính. Một lớp tiếng Anh bậc 3 (B1) tham gia đóng vai nói trực tiếp và một lớp tham gia thảo luận trực tuyến đồng thời. Đối tượng nghiên cứu hoàn thành phiếu điều tra đầu kỳ và cuối kỳ. Ngoài ra, người nghiên cứu cũng phỏng vấn nhóm thảo luận qua máy tính để điều tra thái độ và đánh giá về giao tiếp đồng thời qua trung gian máy tính đối với việc phát triển kỹ năng ngôn ngữ. Phân tích phiếu điều tra và phỏng vấn cho thấy khóa học tiếng Anh 15 tuần góp phần phát triển kỹ năng ngôn ngữ của sinh viên. Sinh viên có thái độ tích cực đối với việc sử dụng giao tiếp đồng thời qua trung gian máy tính và họ hài lòng với các hoạt động trong phòng máy. Nhóm thảo luận qua máy tính tự tin hơn nhóm đóng vai nói trực tiếp. Điều này cho thấy thảo luận trực tuyến đồng thời sẽ thúc đẩy sinh viên học tiếng Anh. Vì vậy, thảo luận trực tuyến đồng thời cho thấy nó có đóng góp có giá trị vào lớp học ngoại ngữ.

Tù khóa: thảo luận trực tuyến đồng thời, đóng vai nói trực tiếp, đánh giá, thái độ của sinh viên, kỹ năng ngôn ngữ, lớp học ngoại ngữ 


\section{APPENDIX A}

\section{PRE-TREATMENT QUESTIONNAIRE}

You are participating in a research study investigating students' evaluation and attitudes towards synchronous computer-mediated communication on language skills development. By filling out this questionnaire, you grant consent for use of the information.

Please fully fill out the following questionnaire.

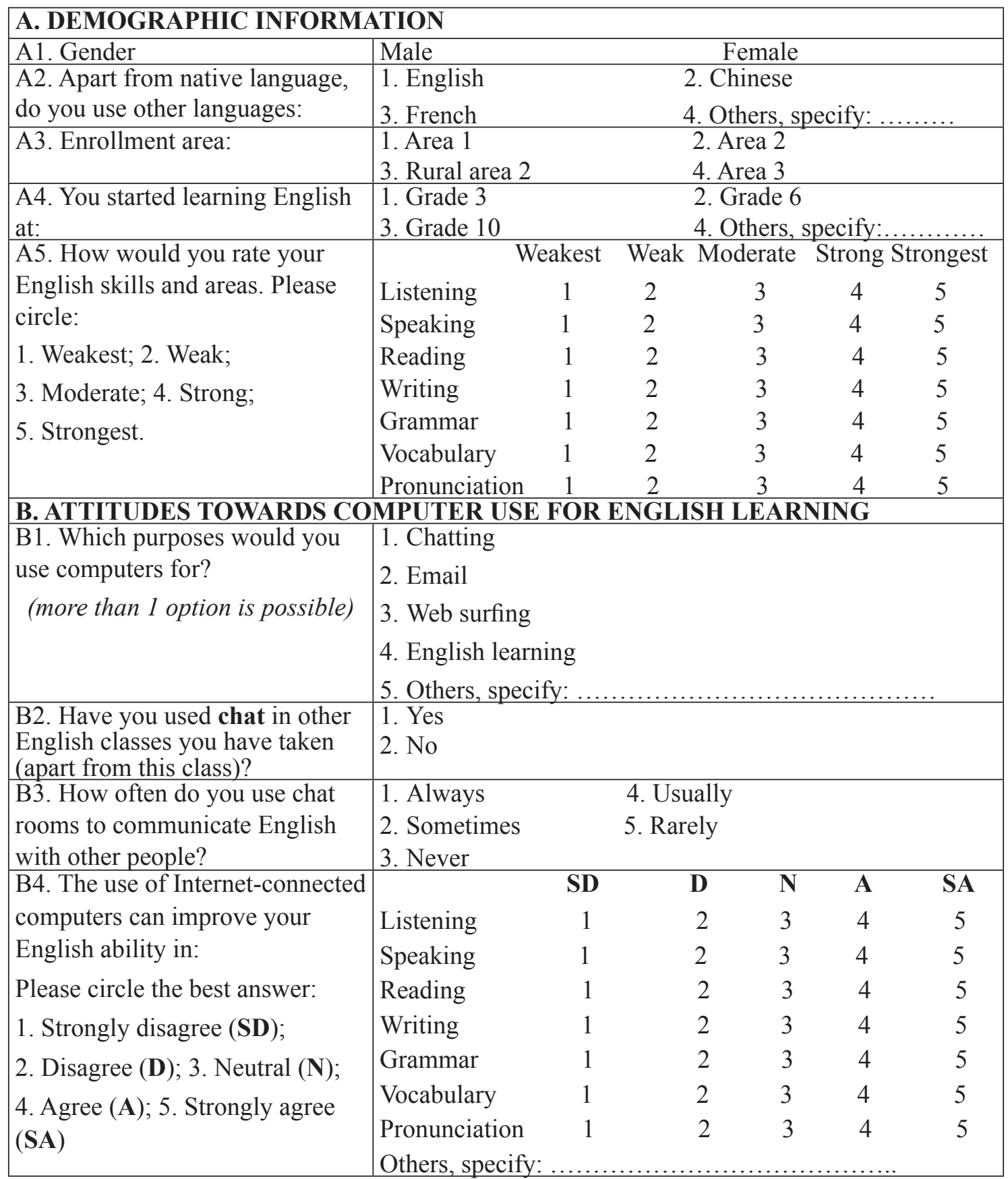




\section{APPENDIX B \\ POST-TREATMENT QUESTIONNAIRE (ROLE PLAY GROUP)}

Please answer the following questions honestly. The purpose of this questionnaire is to provide the researcher of this project with background information concerning your evaluation of and attitude towards the use of technology in a foreign language class.

Please put a cross (X) in the most appropriate cell, which corresponds to the five-level scale given below.

SD $=$ Strongly disagree $\quad \mathbf{D}=$ Disagree $\quad \mathbf{N}=$ Neutral $\quad \mathbf{A}=$ Agree $\quad \mathbf{S A}=$ Strongly agree

\begin{tabular}{|c|c|c|c|c|c|c|}
\hline No. & Statement & SD & D & $\mathbf{N}$ & A & SA \\
\hline \multicolumn{7}{|c|}{ A. Students' self-evaluation of technology application on language skills development via role play } \\
\hline A1. & Doing role plays improved my ability to write in English. & & & & & \\
\hline A2. & Doing role plays improved my ability to read in English. & & & & & \\
\hline A3. & Doing role plays improved my ability to speak in English. & & & & & \\
\hline A4. & Doing role plays improved my ability to listen in English. & & & & & \\
\hline \multicolumn{7}{|c|}{ B. Students' attitudes towards using technology via oral role play } \\
\hline B1. & $\begin{array}{l}\text { Doing role plays in the computer lab was a positive addition to English } \\
\text { intensive class. }\end{array}$ & & & & & \\
\hline B2. & The role plays were too short. & & & & & \\
\hline B3. & $\begin{array}{l}\text { I felt more confident participating in the role plays than in the regular } \\
\text { class. }\end{array}$ & & & & & \\
\hline B4. & I would have preferred to do an online chat instead of an oral role play. & & & & & \\
\hline B5. & $\begin{array}{l}\text { The time we spent on the role plays could have been used more } \\
\text { productively as regular class time. }\end{array}$ & & & & & \\
\hline B6. & $\begin{array}{l}\text { I would have liked to do more role plays in small groups (instead of } \\
\text { just with my partner). }\end{array}$ & & & & & \\
\hline B7. & $\begin{array}{l}\text { I enjoy written assignments more than role plays because they allow } \\
\text { me to monitor my use of grammar and vocabulary, and to be creative } \\
\text { and play around with the language. }\end{array}$ & & & & & \\
\hline B8. & Networked computers have positive contribution to language learning. & & & & & \\
\hline B9. & $\begin{array}{l}\text { I often feel "put on the spot" when doing role plays in English and wish I } \\
\text { had more time to compose "good English" when asked to do a role play. }\end{array}$ & & & & & \\
\hline B10. & $\begin{array}{l}\text { I usually do not feel stressed when answering a question or doing role } \\
\text { plays in the regular class. }\end{array}$ & & & & & \\
\hline B11. & $\begin{array}{l}\text { Having to worry about pronunciation made me feel a lot less } \\
\text { comfortable in the role plays. }\end{array}$ & & & & & \\
\hline B12. & $\begin{array}{l}\text { I monitored my use of grammar and vocabulary in the oral role plays in } \\
\text { the computer lab more than I usually do in the classroom. }\end{array}$ & & & & & \\
\hline B13. & $\begin{array}{l}\text { I noticed other students' mistakes more when they presented their oral } \\
\text { role plays in the lab than in oral communication in the regular class. }\end{array}$ & & & & & \\
\hline
\end{tabular}




\section{APPENDIX C}

\section{POST-TREATMENT QUESTIONNAIRE (SCMC GROUP)}

Please answer the following questions honestly. The purpose of this questionnaire is to provide the researcher of this project with background information concerning your evaluation of and attitude towards the use of technology in a foreign language class.

Please put a cross $(\mathrm{X})$ in the most appropriate cell, which corresponds to the five-level scale given below.

$$
\text { SD }=\text { Strongly disagree } \quad \mathbf{D}=\text { Disagree } \quad \mathbf{N}=\text { Neutral } \quad \mathbf{A}=\text { Agree } \quad \mathbf{S A}=\text { Strongly agree }
$$

\begin{tabular}{|c|c|c|c|c|c|c|}
\hline No. & Statement & SD & $\mathbf{D}$ & $\mathbf{N}$ & $\mathbf{A}$ & SA \\
\hline \multicolumn{7}{|c|}{$\begin{array}{l}\text { A. Students' self-evaluation of technology application on language skills development via } \\
\text { written chat }\end{array}$} \\
\hline A1. & Using chat improved my ability to write in English. & & & & & \\
\hline A2. & Using chat improved my ability to read in English. & & & & & \\
\hline A3. & Using chat improved my ability to speak in English. & & & & & \\
\hline A4. & Using chat improved my ability to listen in English. & & & & & \\
\hline \multicolumn{7}{|c|}{ B. Students' attitudes towards using technology via written chat } \\
\hline B1. & $\begin{array}{l}\text { Using chat in the computer lab was a positive addition to } \\
\text { English intensive class. }\end{array}$ & & & & & \\
\hline $\mathrm{B} 2$. & The chat sessions were too short. & & & & & \\
\hline B3. & $\begin{array}{l}\text { I felt more confident participating in the chat than in the regular } \\
\text { class. }\end{array}$ & & & & & \\
\hline B4. & $\begin{array}{l}\text { I would have preferred to do an oral role play instead of the } \\
\text { chat. }\end{array}$ & & & & & \\
\hline B5. & $\begin{array}{l}\text { The time we spent on the chat could have been used more } \\
\text { productively as regular class time. }\end{array}$ & & & & & \\
\hline B6. & $\begin{array}{l}\text { I would have liked to chat more often in small groups (instead } \\
\text { of just with my partner). }\end{array}$ & & & & & \\
\hline B7. & $\begin{array}{l}\text { I enjoy oral role plays more than written assignments (e.g., } \\
\text { essays), because they allow me to be creative and play around } \\
\text { with the language. }\end{array}$ & & & & & \\
\hline B8. & $\begin{array}{l}\text { Networked computers have positive contribution to language } \\
\text { learning. }\end{array}$ & & & & & \\
\hline B9. & $\begin{array}{l}\text { I often feel "put on the spot" when doing role plays in English } \\
\text { and wish I had more time to compose "good English" when } \\
\text { asked to do a role play. }\end{array}$ & & & & & \\
\hline B10. & $\begin{array}{l}\text { I usually do not feel stressed when answering a question or } \\
\text { doing role plays in the regular class. }\end{array}$ & & & & & \\
\hline B11. & $\begin{array}{l}\text { Not having to worry about pronunciation made me feel a lot } \\
\text { more comfortable in the online discussions. }\end{array}$ & & & & & \\
\hline B12. & $\begin{array}{l}\text { I monitored my use of grammar and vocabulary in the chat } \\
\text { messages more than I usually do in oral communication. }\end{array}$ & & & & & \\
\hline B13. & $\begin{array}{l}\text { I noticed other students' mistakes more when conversing in the } \\
\text { chat than in oral communication in the regular class. }\end{array}$ & & & & & \\
\hline
\end{tabular}




\section{APPENDIX D \\ POST-TREATMENT INTERVIEW (SCMC GROUP)}

1. How would you describe the course? What are your feelings about the course?

2. Which language skills (speaking, writing, reading, listening) do you think you improved most during the course? How and Why?

3. What do you think about monitoring the use of grammar and vocabulary during chat sessions?

4. What do you think about noticing other students' mistakes during chat sessions? What did you do with found mistakes?

5. What do you think about writing text chat on language development?

6. What major changes do you perceive after the course?

7. Which would you prefer learning English: online chat or attend regular class? Why?

8. What do you think you will do to improve your English after this course?

Thank you for your cooperation! 